\title{
Sistem Pendukung Keputusan Pemilihan Negara Untuk Studi S1 di Asia Tenggara Berbasis Website dengan Menggunakan Metode Topsis
}

\author{
Fitria Nugrahani, Paramidita Nurul Hayati, Iklima Ermis Ismail \\ Jurusan Teknik Informatika dan Ko mputer \\ Politeknik Negeri Jakarta \\ fitria.nugrahani@tik.pnj.ac.id, paramidita.25.9f@g mail.com, iklimaermis.is mail@tik.pnj.ac.id
}

Diterima: 19 Oktober 2018. Disetujui 25 Oktober 2018. Dipublikasikan Nope mber 2018

\begin{abstract}
Southeast Asia is one part of the A sian country that has many leading universities, one of them in Indonesia. Therefore, many students wish to continue their undergraduate studies in Southeast Asia. However, students sometimes feel confused choosing a destination country for undergraduate study in Southeast Asia. Based on these problems, the authors make Decision Support System of State Election for Study S1 in Southeast Asia to assist students in choosing a country for study S1. The author makes this decision support system using 5 States as an alternative.This System using TOPSIS Method to calculate and determine which countries that would be the best recommendation for studies. This method could be effective for the recommendation.

Keywords : South East A sia, TOPSIS, DSS
\end{abstract}

\section{PENDAHULUAN}

Studi S1 atau Strata 1 Merupakan Studi yang dilakukan setelah Seorang Siswa Lulus dari Sekolah Tingkat Menengah Atas untuk melanjutkan studi ke Perguruan Tinggi, atau Mahasiswa program studi D3 yang ingin melanjutkan studi S1.Dalam hal ini, siswa atau mahasiswa akan me milih tempat atau universitas yang cocok untuk melanjutkan studi kuliahnya. Siswa atau mahasiswa juga dapat memilih apakah akan melanjutkan studi nya di dalam atau di luar negeri. Ada beberapa universitas terkemu ka di negara-negara Asia Tenggara, termasuk Indonesia. Adapun prospek dan pengalaman akan didapat lebih besar di luar Negeri. Seperti dapat meningkatkan kemampuan bahasa inggris, menambah wawasan[1], mendapatkan relasi atau teman dari negara lain, berkesempatan menyaksikan, memahami, dan mengapresiasi budaya langsung dari suatu negara [2], dan pengalaman lainnya.

Namun, berdasarkan hasil wawancara dengan agensi studi ke luar negeri, didapatkan informasi bahwa terkadang siswa kerap merasa bingung untuk melanjutkan studi nya di dalam atau di luar negeri. Oleh karena itu dibuat Sistem Pendukung Keputusan untuk pemilihan Negara khususnya di Wilayah Asia Tenggara untuk studi S1.

Sistem Pendukung Keputusan ini menggunakan Metode Tops is yang akan menghasilkan perankingan alternatif negara sehingga dapat membantu siswa untuk memilih negara di Asia Tenggara yang cocok untuk studi S1. Kriteria-kriteria yang ada pada aplikasi sistem pengambilan keputusan ini yaitu biaya hidup, biaya studi, peringkat universitas, peringkat jurusan, dan Nilai TOEFL. Untuk pencarian data mengenai kriteria-kriteria tersebut pada setiap negara di Asia Tenggara, penulis bekerja sama dengan agensi.

\section{TINJ UAN PUS TAKA}

\section{A. Website}

Website dapat diartikan sebagai kumpulan halaman-halaman yang digunakan untuk me mpublikasikan informasi berupa teks, gambar, dan program multimedia lainnya berupa animasi (gambar gerak, tulisan gerak), suara, dan atau gabungan dari semuanya itu baik yang bersifat statis maupun dinamis yang me mbentuk satu rangkaian bangunan yang saling terkait antara satu halaman dengan halaman yang lain yang sering disebut sebagai hyperlink Dalam pengertian yang lain bahwa website adalah kumpulan dari halaman-halaman situs yang biasanya terangkum dalam sebuah domain atau subdomain, yang tempatnya berada di dalam World Wide Web [3].

\section{B. Sistem Pendukung Keputusan}

Sistem Pendukung Keputusan (SPK) merupakan sistem berbasis komputer interakt if yang membantu pengambil keputusan memanfaatkan data dan model untuk menyelesaikan suatu masalah. SPK terdiri dari tiga komponen utama, yakni manajemen 
model, manajemen data, dan antarmuka. Terdapat empat fase dalam pembangunan sistem pendukung keputusan, yaitu intelligence, design, choice, dan implementation [4].

Sistem Pendukung Keputusan (SPK) atau Decision Support System (DSS) adalah salah satu dari sistem informasi berbasis komputer dengan melakukan pengolahan data menjadi informasi. Dalam SPK informasi tersebut berupa rekomendasi atau solusi alternatif dari permasalahan yang diangkat. Sistem pendukung keputusan merupakan sistem informasi interaktif yang menyediakan informasi, pemodelan dan memanipulasi data [5]. Sistem pendukung keputusan biasanya dirancang untuk mendukung solusi atas suatu masalah atau untuk mengevaluasi suatu peluang.

\section{Strata Satu}

Strata Satu adalah tingkat pendidikan yang memberikan gelar Sarjana dengan masa pendidikan empat sampai lima tahun. Sarjana merupakan jenjang pendidikan Strata-1 atau biasa disingkat S1 atau disebut juga Bachelor. Gelar Sarjana ditulis di belakang nama lu lusan program studi Sarjana dengan mencamtumkan huruf " $S$ ' atau huruf "B" untuk gelar Bachelor. [6].

\section{Asia Tenggara}

Asia Tenggara adalah sebuah kawasan di benua Asia bagian tenggara. Kawasan ini mencakup Indochina dan Semenanjung Malaya serta kepulauan di sekitarnya. Asia Tenggara berbatasan dengan Republik Rakyat Tiongkok di sebelah utara, Samudra Pasifik di timur, Samudra Hindia di selatan, dan Samudra Hindia, Teluk Benggala, dan anak benua India di barat [7].

Asia Tenggara biasa dipilah dalam dua kelompok: Asia Tenggara Daratan (ATD) dan Asia Tenggara Maritim (ATM). Negara-negara yang termasuk ke dalam Asia Tenggara Daratan adalah Kamboja, Laos, Myanmar, Thailand, dan Vietnam. Negara-negara yang termasuk ke dalam Asia Tenggara Maritim adalah Brunei, Filipina, Singapura, Malaysia, Indonesia, dan Timor Leste [7].

\section{E. Metode TORSIS}

TOPSIS adalah sebuah metode MADM yang didasarkan pada konsep dimana alternatif terpilih yang terbaik hanya memiliki jarak terpendek dari solusi ideal positif, namun juga memiliki jarak terpanjang dari solusi ideal negatif [8]. TOPSIS mempertimbangkan solusi ideal positif dan solusi ideal negatif, jarak terhadap solusi ideal positif dan jarak terhadap solusi ideal negatif dengan mengambil kedekatan relatif terhadap solusi ideal positif. Berdasarkan perbandingan terhadap jarak relatifnya, susunan prioritas alternatif bisa dicapai [9]. Konsep ini banyak digunakan pada beberapa model MADM untu menyelesaiakan masalah keputusan secara praktis. Hal ini disebabkan karena konsepnya sederhana dan mudah dipahami, komputasinya efisien, dan memiliki kemampuan untuk mengukur kinerja relatif dari alternatif-alternatif keputusan dalam bentuk matematis yang sederhana.

Secara umum, langkah-langkah penyelesaian dengan menggunakan metode TOPSIS :

1. Membuat matriks keputus an yang ternormalisasi Matrik keputusan ternormalisasi dihitung berdasarkan :

$$
r_{\bar{i}}=\frac{x_{\bar{g}}}{\sqrt{\sum_{i=1}^{m} x_{i j}^{2}}}
$$

dengan $\mathrm{i}=1,2 . . \mathrm{m}$ dan $\mathrm{j}=1,2, \ldots \mathrm{n}$

2. Membuat matriks keputus an yang ternormalisasi terbobot. Matriks keputusan normalisasi terbobot dihitung berdasarkan :

$$
y_{i j}=w_{i} r_{i j}
$$

dimana $i=1,2 . . m$ dan $j=1,2, \ldots$

3. Menentukan matriks solusi ideal positif dan matriks solusi ideal negatif

Solusi ideal positif $A+$ dan solusi ideal negatif A-dapat ditentukan berdasarkan rating terbobot ternormalisasi (yij), yaitu :

$$
\begin{aligned}
& A^{+}=y_{1}^{+}, y_{2}^{+}, \ldots, y_{n}^{+} \\
& A^{-}=y_{1}^{-}, y_{2}^{-}, \ldots, y_{n}^{-}
\end{aligned}
$$

Dimana :

$$
\begin{aligned}
& y_{j}^{+}=\left\{\begin{array}{l}
\max y_{i} ; j i k a j \text { adalahatrbut keuntungan } \\
\underset{i}{\min y_{i}} ; j i k a j \text { adalahatribut biaya }
\end{array}\right. \\
& y_{j}^{-}=\left\{\begin{array}{l}
\min _{i} y_{i} ; j i k a j \text { adalahatribut keuntungan } \\
m_{i} a x y_{i} ; j i k a j \text { adalahatribut biaya }
\end{array}\right.
\end{aligned}
$$

4. Menentukan jarak antara nilai setiap alternatif dengan matriks solusi ideal positif dan matriks solusi ideal negatif

Jarak antara nilai setiap alternatif dengan matriks solusi ideal positif dirumuskan sebagai :

$$
\begin{gathered}
D_{i}^{+}=\sqrt{\sum_{j=1}^{n}\left(y_{i}^{+}-y_{\bar{j}}\right)^{2}} \\
\text { dimana } \mathrm{i}=1,2, \ldots \mathrm{m}
\end{gathered}
$$

5. Menentukan nilai preferensi untuk setiap alternatif. Nilai preferensi untuk setiap alternatif (Vi) dirumuskan sebagai [10]: 


$$
V_{i}=\frac{D_{i}^{-}}{D_{i}^{-}+D_{i}^{+}}
$$

$$
\text { dimana } \mathrm{i}=1,2, . . \mathrm{m}
$$

\section{ANALIS IS DAN PERANCANGAN SISTEM}

\section{A. Use Case Diagram}

Gambar 1 menunjukkan bahwa terdapat satu aktor pada aplikasi ini, user dapat melihat hasil perankingan alternatif negara untuk studi S1 di Asia Tenggara dengan memasukkan atau menentukan bobot tiap kriteria. Selain itu, User juga dapat melihat informasi peringkat universitas, biaya studi, dan biaya hidup.

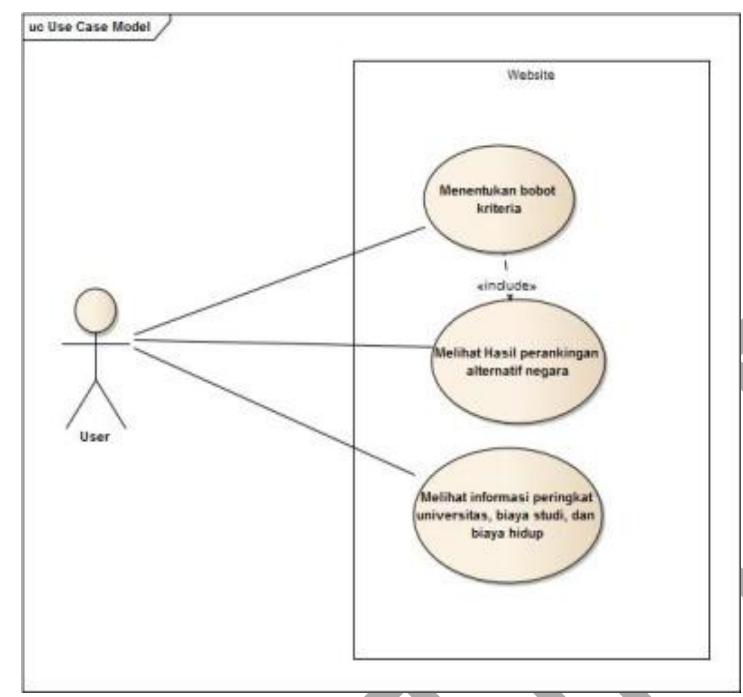

Gambar 1 Use Case Diagram

\section{B. Activity Diagram}

Gambar 2 menunjukkan bahwa apabila user ingin melihat hasil perankingan alternatif negara, user mengakses halaman utama terlebih dahulu, setelah sistem menampilkan halaman utama, kemudian user klik menu "start" dan sistem akan menampilkan halaman input bobot kriteria. Setelah itu user memasukkan bobot tiap kriteria dan klik tombol "process", maka sistem akan memproses perhitungan DSS dengan menggunakan metode TOPSIS, dan sistem akan menampilkan ranking alternatif negara dan user dapat melihat hasil peran kingan tersebut.

\section{Sequence Diagram}

Gambar 3 menunjukkan bahwa user terlebih dahulu mengakses halaman utama, kemudian setelah masuk ke form input bobot kriteria, user me masukkan bobot setiap kriteria, setelah itu bobot tiap kriteria akan memproses perhitungan DSS dan sistem akan menampilkan hasil perankingan alternatif negara yang dapat dilihat oleh user.
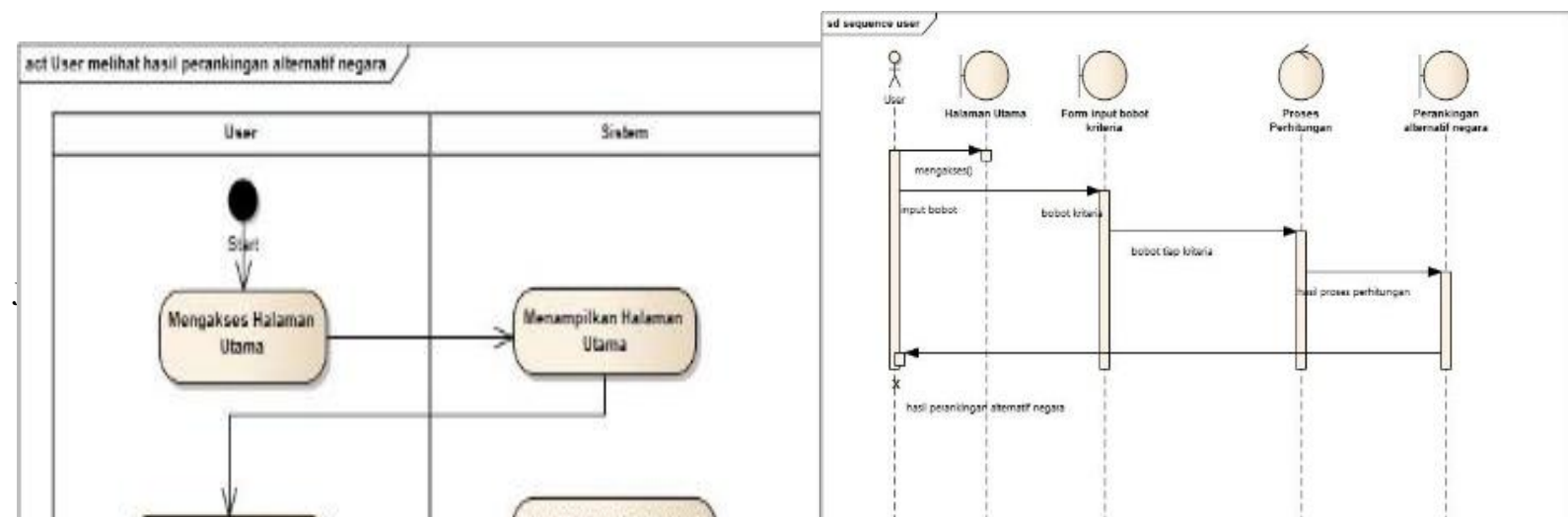
Gambar 3 Sequence Diagram

\section{Entity Relationship Diagram}

Gambar 4 menunjukkan bahwa terdapat satu relasi memiliki yang menghubungkan entitas negara dan universitas. Sehingga entitas negara memiliki entitas universitas. Satu negara memiliki banyak universitas. Entitas negara memiliki beberapa atribut yaitu id_negara, nama_negara, biaya_studi dan biaya_hidup. Sedangkan entitas universitas memiliki atribut id_universitas, nama_universitas peringkat_universitas, dan negara_universitas.

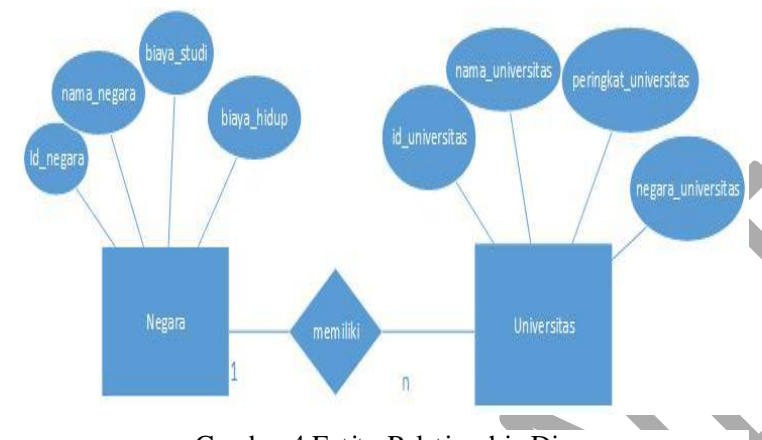

Gambar 4 Ent ity Relationship Diagram

\section{IMPLEMENTAS I SIS TEM}

A. Implementasi Interface Halaman Website

1) Halaman Utama

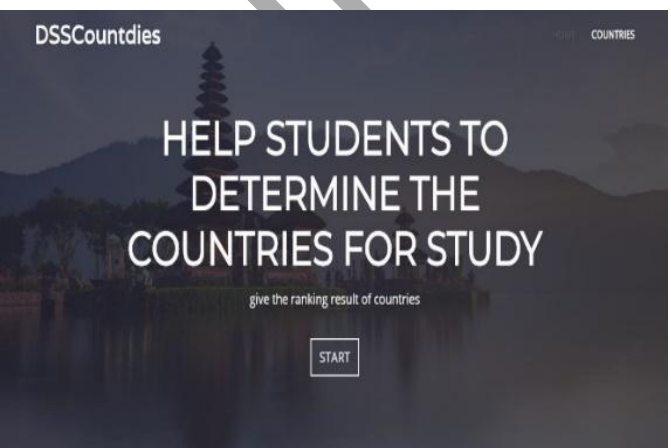

Gambar 5 Halaman Utama

website sistem pendukung keputusan untuk studi S1 di Asia Tenggara. Interface halaman utama ini menggunakan background gambar slider. Terdapat menu start untuk memulai penerapan sistem pendukung keputusan.

2) Halaman Input Bobot Kriteria

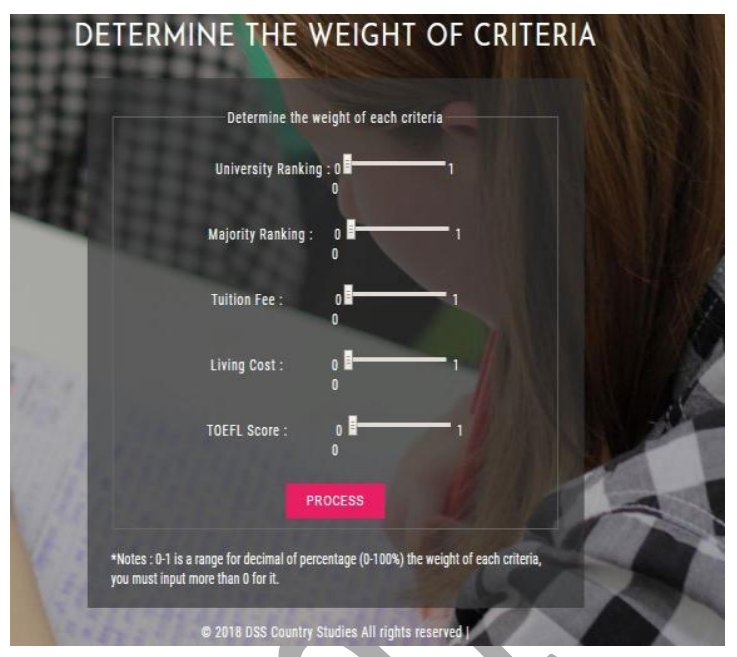

Gambar 6 Halaman input bobot kriteria

Gambar 6 menunjukkan halaman untuk memasukkan bobot tiap kriteria dari user. Pada halaman ini menggunakan range input 0-1 yang merupakan bentuk desimal dari $0-100 \%$, user harus memasukkan bobot lebih dari 0 untuk mendapatkan hasil perhitungan sistem pendukung keputusan, setelah input bobot tiap kriteria, user klik tombol "process".

\section{3) Halaman Countries}

\section{DSSCountdies}

COUNTres

\section{COUNTRIES}

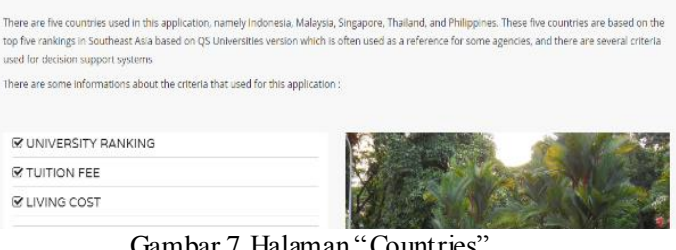

Gambar 7 Halaman "Countries"

Gambar 7 menunjukkan bahwa pada halaman "Countries" terdapat informasi mengenai Peringkat Universitas, biaya studi, dan biaya hidup tiap negara di 5 negara di Asia Tenggara (Indonesia, Singapura, Thailand, Malaysia, dan Filipina).

\section{DSSCountdies}

COUNTRIES

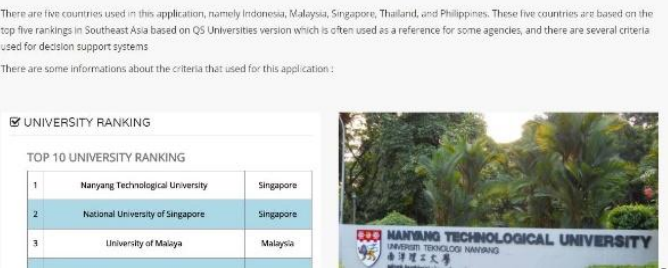

Gambar 8 Halaman informasi peringkat universit as pada halaman "Countries" 


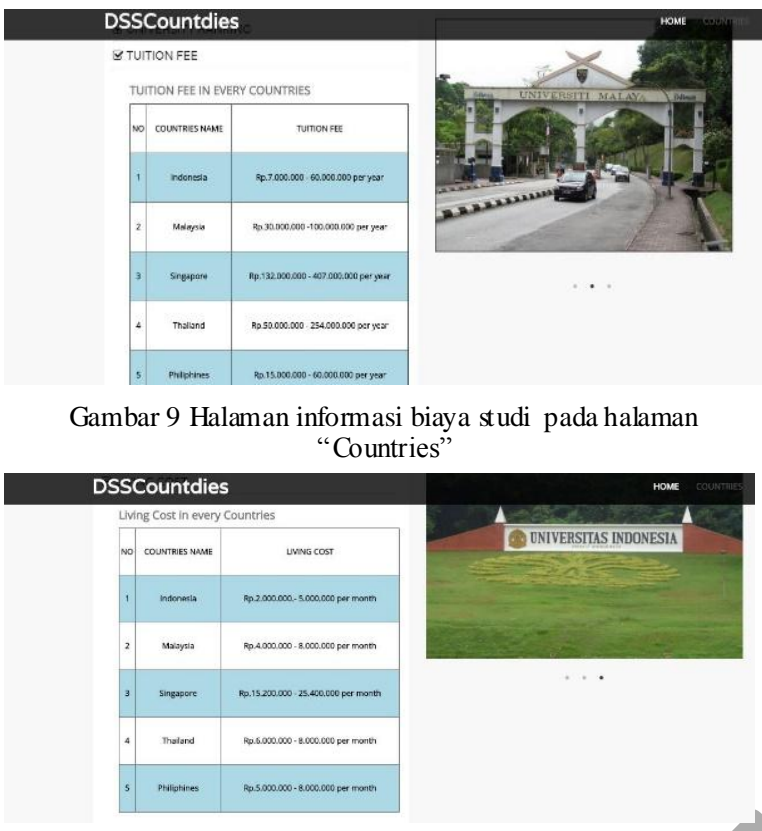

Gambar 10 Halaman informasi biaya hidup pada halaman "Countries"

Gambar 8, 9 dan 10 menunjukkan halaman informasi peringkat universitas, biaya studi, dan biaya hidup di lima negara di Asia Tenggara pada halaman "Countries".

\section{B. Implementasi Metode TOPSIS}

Setelah data alternatif dan kriteria setiap negara telah didapat, maka dibuatlah suatu nilai untuk tiap kriteria. Nilai kriteria untuk kriteria peringkat universitas dan peringkat jurusan, telah ditetapkan nilai 1 - 5, dimana peringkat tersebut merupakan dari peringkat tertinggi sampai terendah. Nilai tersebut ditetapkan berdasarkan peringkat yang didapat dari website QS Universities.

Nilai untuk kriteria biaya hidup, biaya studi, dan Nilai TOEFL ditetapkan berdasarkan konversi range dari nilai yang sesungguhnya pada kriteriakriteria tersebut dan telah ditetapkan konversi nilai dari 1-3. kriteria peringkat universitas, peringkat jurusan, biaya hidup, dan biaya studi sebagai cost , sedangkan kriteria nilai TOEFL sebagai benefit.

Adapun konversi range dari data tiga kriteria tersebut ke dalam angka adalah sebagai berikut:

TABEL 1 KONVERSI RANGE DATA KRITERIA BIAYA HIDUP KE DALAM BENT UK ANGKA

\begin{tabular}{|l|l|l|}
\hline No & Nilai atau range & $\begin{array}{l}\text { Konversi ke dalam } \\
\text { bentuk angka }\end{array}$ \\
\hline 1 & Rp. $2.000 .000 .-5.000 .000$ & 1 \\
\hline 2 & Rp. $4.000 .000 .-8.000 .000$ & 2 \\
\hline
\end{tabular}

\begin{tabular}{|l|l|l|}
\hline 3 & Rp.10.000.000. -20.000 .000 & 3 \\
\hline
\end{tabular}

TABEL 2 KONVERSI RANGE DATA KRITERIA BIAYA STUDI KE DALAM BENTUK ANGKA

\begin{tabular}{|l|l|l|}
\hline No & Nilai atau range & $\begin{array}{c}\text { Konversi ke dalam } \\
\text { bentuk angka }\end{array}$ \\
\hline 1 & Rp. $7.000 .000 .-60.000 .000$ & 1 \\
\hline 2 & Rp. $30.000 .000 .-100.000 .000$ & 2 \\
\hline 3 & Rp. $100.000 .000 .-400.000 .000$ & 3 \\
\hline
\end{tabular}

TABEL 3 KONVERSI RANGE DATA KRITERIA NILAI TOEFL KE DALAM BENTUK ANGKA

\begin{tabular}{|c|c|c|}
\hline No & Nilai atau range & $\begin{array}{c}\text { Konversi ke dalam } \\
\text { bentuk angka }\end{array}$ \\
\hline 1 & $400-500$ & 1 \\
\hline 2 & $500-550$ & 2 \\
\hline 3 & $550-600$ & 3 \\
\hline
\end{tabular}

Setelah didapatkan Nilai setiap kriteria, maka dilakukan perhitungan TOPSIS. Microsoft Excel digunakan sebagai Tools untuk perhitungan manual. Perhitungan dengan Microsoft Excel merujuk pada lampiran. Adapun langkah-langkah perhitungan dengan metode TOPSIS dilakukan berdasarkan langkah-langkah pada persamaan 1 hingga persamaan 5 seperti yang telah dituliskan pada tinjauan pustaka metode TOPSIS.

\section{RESULT OF ALTERNATIVE COUNTRIES RANKING}

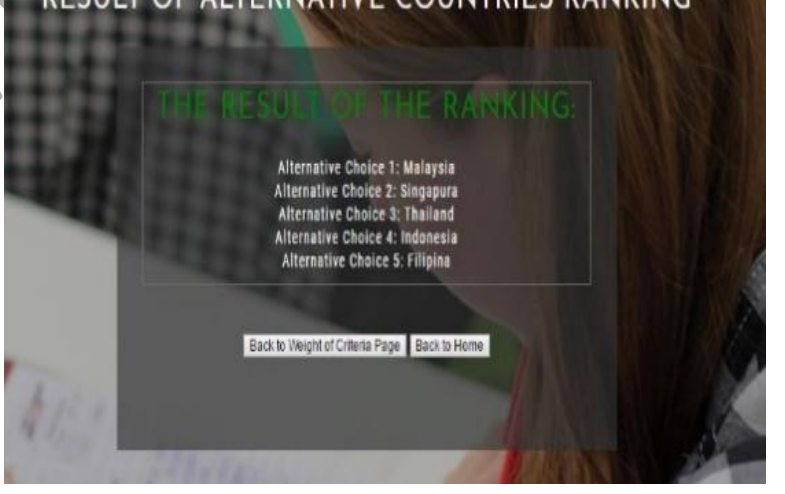

Gambar 11 Halaman Hasil Perankingan Alternat if Negara

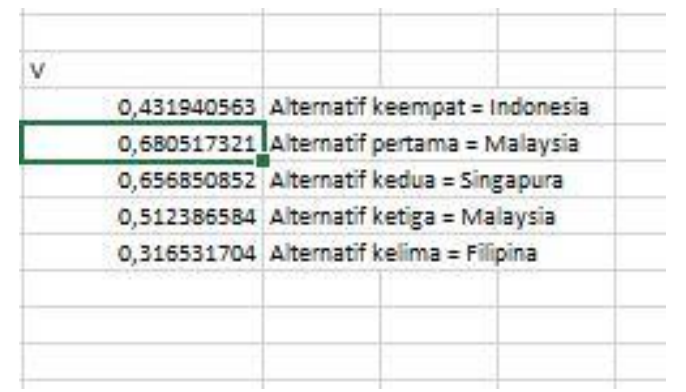


Gambar 12 Hasil Perankingan Alternat if Negara menggunakan Microsoft Excel

Gambar 12 Menunjukkan hasil perankingan alternatif negara yang didapat oleh user setelah memasukkan input bobot kriteria pada halaman input bobot kriteria dan mengklik to mbol "process". Hasil perhitungan didapatkan berdasarkan perhitungan menggunakan metode TOPSIS, dan pada gambar 12 menunjukkan hasil perankingan alternative negara secara manual dengan menggunakan Micros oft Excel.

\section{KES IMPULAN}

Sistem Pendukung Keputusan Pemilihan Negara untuk Studi S1 di Asia Tenggara berbasis web yang telah dibuat diharapkan berfungsi dengan baik dan dapat bermanfaat bagi para siswa yang merasa bingung dalam memilih negara untuk studi S1 di Asia Tenggara. Sistem ini dapat membantu menghasilkan perankingan alternatif negara untuk studi S1 di Asia Tenggara dengan menggunakan perhitungan metode TOPSIS dan dapat memberikan informasi mengenai peringkat universitas, biaya studi, dan biaya hidup pada lima negara di Asia Tenggara.

\section{REFERENS I}

[1] Gramedia, K. (2005), kuliah ke luar negeri itu mudah, Kompas, Jakarta

[2] Rusdi, D. (2010), Kuliah Gratis ke Luar Negeri, mau?, Lingkar Pena Publishing House.

[3] Marisa, F. (2017), Web Programming (Client Side and Server Side), En-Deepublish.

[4] Turban, d. (2011), Decision Support and and Business Intelligent System, Pearson Education Inc, New Jersey.

[5] Saragih, S. H. (2013), Penerapan Metode Analytical Hierarchy Process Pada Sistem Pendukung Keputusan Pemilihan Laptop, Jurnal Pelit a Informat ika Budi Darma , IV(Agustus 2013), p. 83. [6] Keputusan Menteri Pendidikan dan Kebudayaan Republik Indonesia No. 036/U/1993 tentang Gelar dan Sebutan Lulusan Perguruan Tinggi.

[7] Encyclopedia, M. E. O. (2005), Southeast Asia, Microsoft Corporation.

[8] Sri Kusumadewi, d. (2011), Fuzzy Multi Attribute Decision Making (Fuzzy MADM), Graha Ilmu, Yogyakarta.

[9] Tri Widayanti, T. W. (2016), Implementasi Metode TOPSIS dalam Sistem Pendukung Keputusan Seleksi Penerima Beasiswa Bidikmisi Berbasis Web, Citec Journal, 3 No.4(Agustus-Oktober 2016), p. 346.

[10]Arifah, D. (2013), Analisa dan Perancangan Sistem Pendukung Keputusan Pemilihan Kendaraan Menggunakan Metode TOPSIS, Jurnal Teknologi Informasi, Volume 5 No.1, pp. 41-42. 